\title{
AC 2007-2456: OUTREACH INITIATIVE FOR RECRUITING WOMEN TO ENGINEERING: DOING A GOOD DEED FOR GIRL SCOUTS
}

\section{David Cottrell, University of North Carolina-Charlotte}

DR. DAVID S. COTTRELL is an Assistant Professor in the Department of Engineering Technology, University of North Carolina at Charlotte. He graduated from the United States Military Academy in 1978 and retired in 2000 after more than 22 years of service with the US Army Corps of Engineers. Studies at Texas A\&M University resulted in an MS Degree in Civil Engineering in 1987 and a PhD in 1995. He is a registered Professional Engineer and has taught courses in statics, dynamics, mechanics of materials, graphic communications, engineering economy, and construction planning, scheduling, estimating, and management. 


\section{Outreach Initiative for Recruiting Women to Engineering: Doing a Good Deed for Girl Scouting}

\section{Introduction}

The youth of today are the leaders of tomorrow. This truth is frequently brought to light by many who would raise an alarm about a perceived trend or character trait contrary to their vision of a secure and robust future; others would sow confidence in a generation from which great things were expected. Current studies indicate that the United States is facing an imminent shortage of scientists, technologists, engineers, and mathematicians; further, female high-school students show little interest in pursuing careers related to engineering. ${ }^{1}$ This lack of interest may be a significant factor in understanding the "Extraordinary Woman Engineers Project" which reported that currently fewer than $10 \%$ of the nation's engineers are women in spite of the fact that girls do not lag behind boys in grades or test scores in either math or science. ${ }^{2}$

The program presented by this paper represents perhaps part of the solution to this paradox by investing in the female youth of today through proven hands-on learning techniques. ${ }^{3}$ This paper reports on a local initiative by the University of North Carolina at Charlotte to invest in the female youth of today through some proven hands-on learning techniques. It envisions an outreach initiative to teach, train, and aid in the learning of female youth of greater Charlotte in the many exciting facets of construction and engineering. However, the program reaches outside the traditional K-12 education system and targets 10-18 year old girls within the Girls Scouts of the Hornets Nest Council in Charlotte, North Carolina. Currently, there are a number of similar, successful institutions in other areas of the country that have developed extensive outreach programs that at least in part encompass Girl Scouts organizations as a significant target of opportunity for enlightening young girls to the exciting possibilities of a career in engineering. At the University of Colorado at Boulder, the College of Engineering and Applied Science offers a variety of hands-on engineering workshops to elementary, middle and high school students as well as teaching support for K-12 teachers to assist them in bringing science and engineering concepts into their classrooms. Their Girl Scout Outreach Program enlightens young women of opportunities in the fields of science and engineering through interactive Girl Scout badges in a fun learning atmosphere. ${ }^{3}$ Working in conjunction with the Society of Women Engineers, the University of Massachusetts Amherst has an outreach program to the Western Massachusetts Girl Scout Council that includes hands-on activities with an engineering focus, guest speakers from industry, and research experience for students. ${ }^{4}$ Ohio State University's outreach program - "Girl Scout Days" - employs workshops sponsored by the Society of Women in Engineering for Girl Scouts to experience engineering first-hand. Through tours, group work, and engineering activities, the participants learn about the fields of math and science and have a glimpse of what it means to be an engineer. ${ }^{5}$ The Hornets Nest Council in Charlotte in cooperation with the Society of Women Engineers and the University of North Carolina at Charlotte has also implemented a number of initiatives to expose their Girl Scouts to a wide variety of engineering topics and disciplines. Their "Professor Buzz" and "Engineers are Cool" programs allow girls to encounter automotive maintenance, electronics, medicine, botany, geology, space, and others. ${ }^{6}$

"Proceedings of the 2007 American Society for Engineering Education Annual Conference \& Exposition Copyright C 2007, American Society for Engineering Education"” 


\section{Significance and Research Objectives}

Reaching young girls at a critical stage when long term decisions are being made about vocations and college, the program components described by this research proposal will provide an inspiring, girl-friendly collection of hands-on activities that inspire young women to explore engineering as a career choice. This program will accomplish the following:

- Introduce female youth to the potential benefits and rewards associated with a career in the field of engineering;

- Educate the Girl Scouts on different types of engineering including civil engineering technology and construction management;

- Increase knowledge of engineering concepts behind the design, planning, and construction of items observed in everyday life (bridges, residential homes, and commercial building);

- Reinforce female participation in engineering as a viable field of study/career choice;

- Demonstrate to students from all backgrounds that engineering is an exciting career path;

- Promote diversity within the engineering program.

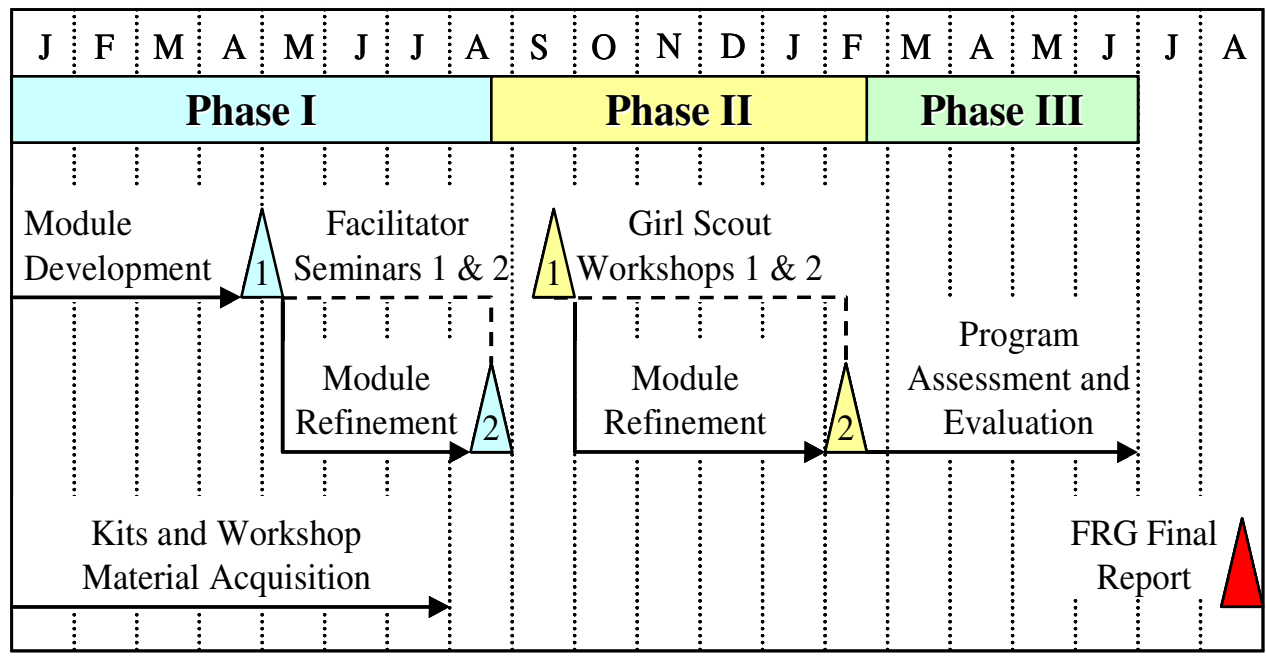

Figure 1. Operational Timeline and Methodology

\section{Operational Concept and Timeline}

Using standard K'Nex and Lincoln Logs building sets, girls will plan, design, and construct a variety of engineering structures including both residential and commercial facilities and bridges. As indicated in Figure 1, this research program will be executed in three phases: I. Preparation; II. Implementation; and III. Assessment and Evaluation. 


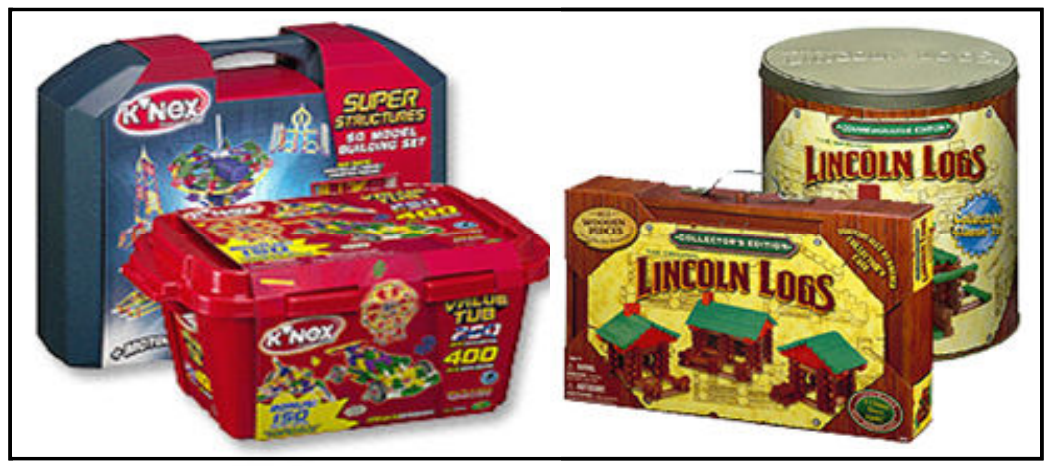

Figure 2. K'Nex and Lincoln Logs Combo Packages

Phase I, "Preparation," includes development of the individual modules for the workshops, material procurement, and facilitator training. The modules will support three distinct instructional tracks involving bridges, residential homes, and commercial facilities. Modules will be developed with input from UNCC student participants during training seminars. Materials available for the three tracks include common commercially available construction toys and kits marketed by K'Nex and Lincoln Logs. (See Figure 2) With inherent flexibility as a prerequisite, each module can be tailored to the education and aptitude level of the participants. Each of the three tracks will have three modules: design, cost estimating, and construction.

- The Design Modules will encompass design-build project delivery methods currently in place within the construction industry. 8,9 Working from a general scope of work, Scouts will develop and sketch several design alternatives.

- The Cost Estimating Modules will allow Girl Scouts to develop a bill of materials based on a selected alternative from the previous module. "Construction materials" will be available from various "vendors" (portrayed by UNCC student facilitators). Girl Scouts will develop a cost and procure the necessary materials.

- Construction Modules will involve building the designed facility with the materials (K'Nex and/or Lincoln Logs) resulting from the previous module. The time required to construct the facility will assist in evaluating team performance.

Phase II, "Module Implementation," will occur during Workshops held at the Girl Scout Council facilities in Charlotte in September and again in February from 9:00 a.m. to 3:00 p.m. The Council will advertise the two workshops among the subordinate scouting organizations and control registration which will be limited at 40 participates. Scouts will be organized into small groups with a UNCC student mentor to aid in execution and completion of each module. Assessment and evaluation of the Fall Workshop \#1 will support adjustment in the design or implementation protocols to improve module effectiveness in accomplishing the program objectives. 
Phase III, "Program Assessment and Evaluation," will be based on input from UNCC student facilitators, girl scout adult administrators, and the scout participants themselves. Although the effectiveness of the individual components of the modules will certainly be evaluated, the primary purpose of the workshop to expose girls to the field of engineering and encourage them to consider a career in science or engineering will be of critical interest. All Girl Scouts will complete a survey both before and after the workshop to address the following points of interest.

- Does the Scout like science?

- Does the Scout like math?

- Does the Scout know what engineers do to create new structures?

- Would the Scout consider a career in science or engineering?

Results of the project will be widely distributed through conferences, and submitted via articles for publication in technical and educational professional society journals and conference proceedings, such as the Society of Women Engineers, the National Association of Women in Education, American Women in Science, and American Society of Engineering Educators.

\section{Conclusion}

This program envisions an outreach initiative to teach, train, and aid in the learning of female youth of greater Charlotte in the many exciting facets of construction and engineering. However, the program reaches outside the traditional K-12 education system and targets 10-18 year old girls within the Girls Scouts of the Hornets Nest Council in Charlotte, North Carolina. This local initiative by the University of North Carolina at Charlotte attempts to invest in the female youth of today through some proven hands-on learning techniques as an outreach to teach, train, and aid in the learning of female youth in the many exciting facets of construction and engineering. However, the program reaches outside the traditional K-12 education system and targets the Girls Scouts of the Hornets Nest Council in Charlotte, North Carolina. Reaching young girls at a critical stage when long term decisions are being made about vocations and college, this outreach initiative perhaps provides an inspiring, girl-friendly collection of hands-on activities that inspire young women to explore engineering as a career choice

\section{Bibliography}

1. Clark, J.V., Minorities in Science and Mathematics: A Challenge for Change, Virginia Parent Information and Resource Center, 2000.

2. "Extraordinary Women Engineers - How They Changed Our World," American Society of Civil Engineers, Reston, Virginia, 25 September 2006. $<\underline{\text { http://www.engineeringwomen.org/execsummary.html }>}$

3. ibid

"Proceedings of the 2007 American Society for Engineering Education Annual Conference \& Exposition Copyright (C) 2007, American Society for Engineering Education” 
4. "Community Outreach," University of Colorado at Boulder, College of Engineering and Applied Science, Bolder, Colorado, 25 September 2006.

$<\underline{\text { http://engineering.colorado.edu/outreach/index.htm }>}$

5. "Community Outreach," University of Massachusetts Amherst, College of Engineering, Amherst, Massachusetts, 25 September 2006.

http://www.ecs.umass.edu/index.pl?id=2243\&isa=Category\&op=show\#girlGirl Scouts

6. Kennedy, Kristina, "Women in Engineering K-12 Events," The Ohio State University, Columbus, Ohio, 25 September 2006, < http://wie.eng.ohiostate.edu/prospective/outreach.htm>

7. "Program Opportunities," Girl Scouts Hornets' Nest Council, Charlotte, North Carolina, 25 September 2006. <http://www.hngirlGirl Scouts.org/programs/opportunities.asp>

8. Gransberg, Douglas D., James E. Koch, and Keith Molenaar, Preparing for Design Build Projects, American Society of Civil Engineers, Reston, Virginia, 2006.

9. Levy, Sidney M., Design Build Project Delivery, McGraw-Hill, New York, New York, 2006.

10. "Value Combo Pack," K'Nex Shopping Home Special Offers, 25 September 2006. $<$ http://www.knex.com/customer/product.php?productid=16792>

11. "Lincoln Logs Combo Pack," K'Nex Shopping Home Lincoln Logs, 25 September 2006. $<$ http://www.knex.com/customer/product.php?productid=16678> 